\title{
Determinants of Stock Liquidity: Forward-Looking Information, Corporate Governance, and Asymmetric Information
}

\author{
Wiwik UTAMI', Putri Dwi WAHYUNI ${ }^{2}$, Lucky NUGROHO ${ }^{3}$
}

Received: September 10, 2020 Revised: November 02, 2020 Accepted: November 16, 2020

\begin{abstract}
The more liquid the capital market, the more attractive it will be for investors to place their money in the capital market. Therefore, the purpose of this study is to investigate the factors that influence stock liquidity of manufacturing sector companies listed on the stock exchange in Indonesia. The independent variables used in this study are forward-looking information disclosure, institutional ownership, foreign ownership, and board activity with information asymmetry as an intervening variable and stock liquidity as the dependent variable. The population of this study is manufacturing sector companies listed on the Indonesian stock exchange (IDX). Samples are selected based on the random sampling method, and the number of samples is calculated based on the Slovin formula. The sample was 59 manufacturers, and data was annual reports (for 2 years) and stock transactions from 2016 to 2017. The results of the study showed that forward-looking information disclosure had a significant effect on information asymmetry. Information asymmetry and foreign ownership have a significant impact on stock liquidity, whereas information asymmetry mediates the relationship between forward-looking disclosures and stock liquidity. Furthermore, the accuracy of information about the certainty of business activity both now and in the future can instill confidence in stakeholders in interacting and cooperating.
\end{abstract}

Keywords: Forward-Looking, Disclosure, Corporate Governance, Asymmetry Information, Stock Liquidity, Indonesia Stock Exchange

JEL Classification Code: G10, G20, M21, M41

\section{Introduction}

The capital market has a vital role in maintaining economic growth. The more stable the capital market, the more attractive it will be for investors to invest their money in the capital market. Furthermore, in placing their capital, investors expect that the money they have invested can provide profitable returns. The liquidity of shares (stock liquidity) is the ability to buy or sell shares quickly and in high volumes without affecting prices and without causing an increase in transaction costs.

${ }^{1}$ First Author. Full Professor, Department of Accounting, Universitas Mercu Buana, Jakarta, Indonesia.

Email: wiwik.utami@mercubuana.ac.id

${ }^{2}$ Assistant Professor, Department of Accounting, Universitas Mercu Buana, Jakarta, Indonesia. Email: putri.dwi@mercubuana.ac.id ${ }^{3}$ Correspondence Author. Assistant Professor, Department of Accounting, Universitas Mercu Buana, Indonesia [Postal Address: Komplek Merpati Blok D No.13, Pegadungan, Kalideres, Jakarta Baray, Indonesia] Email: Lucky.Nugroho@mercubuana.ac.id

(C) Copyright: The Author(s)

This is an Open Access article distributed under the terms of the Creative Commons Attribution Non-Commercial License (https://creativecommons.org/licenses/by-nc/4.0/) which permits unrestricted non-commercial use, distribution, and reproduction in any medium, provided the original work is properly cited.
Stock liquidity can be measured by trading frequency, transaction volume, and transaction value of a stock. Stock liquidity is one of the key criteria that must be considered by investors before conducting stock analysis from both the technical aspect and fundamental aspect (Utami et al., 2017). In 2017 , local capital market liquidity was relatively low. There are more than 500 shares listed on the Indonesia Stock Exchange (IDX). However, only a small percentage of shares have a daily transaction value above Rp10 billion. Of the 500 plus shares, only $20 \%$ or approximately 115 shares have daily transaction values above Rp10 billion. IDX Director of Corporate Valuation, Samsul Hidayat, said that one way to increase stock liquidity is to improve the mechanism of the Initial Public Offering (IPO) for companies that want to market their stock (IPOTNews, 2017). The liquidity of the stock market in Indonesia has long been considered not optimal. There were many stocks listed on the IDX that were not actively traded or immovable until March 2017. Since 2013, around 27 companies have been delisted from the IDX after being suspended for months and debarred from trading.

One reason for suspension or termination of trade is because there is no stock movement and no financial reporting. According to Susi Melina (Chairman of the Indonesian 
Securities Companies Association-APEI), 80\% of shares are liquid (Forddanta, 2016). The Efficient Market Theory (EMT) states that the stock price, volume, and frequency of trading shares in the market are a reflection of the information and conditions that exist. Investors react quickly to new information to decide to enter the market to invest their capital such that the adjustment effect of stock prices happens immediately (Nofsinger, 2001). However, Ball and Brown (1968), Fama (1969). Lai et al. (2009) stated that stock prices will change when there is useful information entering the market.

Besides, the implementation of good corporate governance (GCG) can increase management oversight to encourage companies to make the right decisions, prevent opportunistic actions that are inconsistent with the interests and objectives of the company. Furthermore, GCG also contributes to reducing information asymmetry between management and company stakeholders (Nugroho \& Nezzim Bararah, 2018; Pernamasari, 2018; Utami et al., 2020). GCG practices reduce the problem of information asymmetry and increase the trust of stakeholders, which will positively impact stock liquidity (Loukil \& Yousfi, 2012). According to Chung et al. (2010) and Wang and Zhang (2009), companies with GCG will have narrower spreads, a lower stock quality index than trade-based information. Disclosure of company information reduces information asymmetry which hampers the allocation of resources in the capital market.

In this study, the quality of CG mechanisms is measured by ownership structures (institutional ownership and foreign ownership), and board activities. The concentration of ownership is very influential in the decision making of a company. The level of ownership is related to the number of shares owned by several shareholders in the share ownership structure. Such property can be owned by the public or non-public, institutional or non-institutional. If external parties dominate share ownership, agency problems between management (as an agent) and shareholder (as principal) can be reduced (Dalton et al., 2007). Furthermore, there is a possibility of a conflict where there is a majority shareholding by certain groups such that there is an opportunity to obtain important information related to the condition of the company where other groups do not get that information. Therefore, the agency problem does not only occur between managers and shareholders and stakeholders but also among shareholders (Dalton et al., 2007).

\section{Literature Review and Hypothesis Development}

In the literature review section, we will provide a theoretical basis related to the variables affecting stock liquidity, which include forward-looking information disclosure, good governance, and information asymmetry. Next, it refers to the phenomena, problem formulation, and literature review of this study so that the hypotheses of this research are established.

\subsection{Agency Theory}

Agency theory put forward by Fama (1969) and Jensen and Meckling (1976), stated that managers are considered agents of the company owner. In large corporations, the owner is unable to supervise the manager directly. Therefore the owner makes a control mechanism to ensure the manager works for their interests. Agency theory assumes that humans are rational, selfish (self-interest), and opportunist beings. With these assumptions, the manager is considered to have the opportunity to take opportunistic actions, namely making policies or acting to maximize their interests than that of the owner or organization. The chance of a conflict of interest with the owner is high because the manager controls more information about the company's operations than the owner (information asymmetry). Managers have extrinsic motivation, which is to obtain satisfaction in the form of money, comfort, and avoid penalties. Therefore, Goodwin (2003) and Sarens et al. (2009) suggested that to reduce conflicts of interest, the principal can oversee the presentation of periodic financial statements made by the agent by empowering the internal audit function and the audit committee. Besides, to reduce conflicts of interest, agents must take into account the trust given by the principals through financial statements that have been audited by external auditors. The audited financial statements should give sufficient assurance that the financial statements presented by the agent are free from material misstatements, thus ensuring that the financial statements can be used by stakeholders to analyze the company (Beretta \& Bozzolan, 2004; Blackwell et al., 1998).

Furthermore, there is the potential for a conflict of interest due to the duties delegated by the principal to the agent for managing the company. The conflict of interest is information asymmetry. According to Arnott and Stiglitz (1988), Igawa and Kanatas (1990), and Vania et al. (2018), information asymmetry is a condition in which there is an imbalance in the acquisition of information between management as a provider of information and shareholders and stakeholders as information users. There are two types of information asymmetry, namely: (i) Adverse selection, that is, managers and other insiders usually know more about the conditions and prospects of the company than outside investors and facts that can influence the decisions of shareholders will make managers not to disclose information to shareholders; (ii) Moral hazard, that is, the activities carried out by managers are not fully known by shareholders or lenders.

\subsection{Forward-Looking Information Disclosure}

Financial reporting includes financial statements and non-financial reports (Hidayah et al., 2019; Skouloudis et al., 2010). Financial reporting is information related to the condition of the company, both current and future conditions. 
Also, there is additional financial information that is grouped into two categories, namely backward-looking information and forward-looking financial information (Ball et al., 2012). Forward-looking financial information can be used by stakeholders and investors to make estimates related to the sustainability of the company. Thus, forward-looking financial information will add value to the company, thereby increasing the trust of investors and stakeholders. Forward-looking financial information will be available to users of financial statements regarding the company's predictions in the future, without having to predict the condition of the company such that users of financial statements can make maximum use of financial information (Alkhatib, 2014). Forward-looking financial information can be in the form of quantitative, qualitative, financial, and non-financial. Furthermore, forward-looking financial information includes estimates of next year's revenue and cash flows to be managed. Also, there is non-financial information that provides information about risks and uncertainties that might significantly affect the actual results causing differences with projections and plans that have been made (Lata, 2020; Wyatt, 2008).

\subsection{Good Corporate Governance (GCG)}

The sustainability of a company's operations is an essential issue for stakeholders, especially investors. The purpose of a company is to have a meaningful vision and then to be profitable in achieving it. The managers and stakeholders have the same interests and goals and to assure that these goals can be achieved and to be able to know the progress transparently, it is necessary to have GCG. GCG aims to oversee the company's processes and activities so that the company's vision and mission, as well as, the strategies implemented are following the commitments and the realization or output is in line with the targets and expectations of all stakeholders (Napitupulu et al., 2020). The implementation of GCG will contribute to the increase in the company's stock price. As such, investors through forward-looking financial information and company reputation can conduct a prediction analysis of the company's future financial conditions (Altman, 1968; Suryo et al., 2019). Thus, there is confidence that investors will get returns in the form of dividends that match their expectations in the future (La Porta et al., 1999). Moreover, the application of GCG in a company can reduce the costs of monitoring and auditing, leading to lower costs of capital (Ammann et al., 2011). However, there are criticisms which state that the adoption of GCG has a higher cost than the contribution of increasing revenue in a company (Chhaochharia \& Grinstein, 2007; Gillan \& Starks, 2005). Also, institutional ownership correlates with GCG, where the majority ownership of shares owned by financial institutions such as banks, insurance, pension funds can improve the function of GCG. That is because the supervision of companies whose shares are owned by financial institutions becomes more active and scheduled, and intense (Herring \& Carmassi, 2008).

\subsection{Stock Liquidity}

Stock liquidity is a vital issue for investors to put their capital into the company. The better the stock liquidity, the more attractive it is for investors to invest their money. According to Edelman and Baker (1990), several factors influence the stock liquidity including the number of shares listed, stock prices, issuer's fundamental factors, information disclosure, and market sentiment. Stock liquidity is an indicator and market response to an announcement measured by Trading Volume Activity (TVA). According to Suryawijaya and Setiawan (1998), Trading Volume Activity (TVA) is an instrument to see the reaction of the capital market to information through the parameters of the volume movement of stock trading activities in the capital market. Nevertheless, Anand et al. (2013) stated that there are four dimensions of stock liquidity namely (1) immediacy (freshness), which measures how quickly investors transact in an asset; (2) width (width of bid-offer spread), where liquidity is seen from the costs that must be borne for the transaction of an asset; (3) depth, where liquidity is seen from the number of buys and sell orders on the market; (4) resiliency, where liquidity is seen from how fast an asset can return to the previous level if there is an imbalance of buying and selling activities in large numbers.

\subsection{Hypothesis Development}

Investor trust is one of the elements that need to be maintained for the company's operational sustainability. However, future business activities are full of uncertainties. Therefore mitigation is required in the form of information that the company can carry out its business activities following the commitments of all stakeholders. Likewise, stock liquidity disclosure will be influenced by forwardlooking information, because with the existence of forwardlooking information, the stakeholders have access to information related to the company's plans and strategies as well as the company's commitment to achieving targets as per the expectations of the stakeholders.

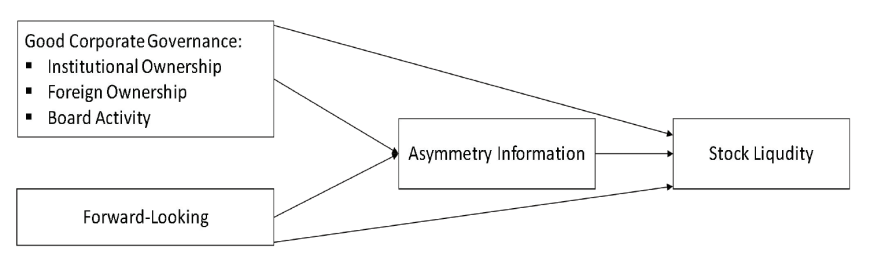

Figure 1: The Conceptual Framework of Hypothesis 
Thus, the existence of forward-looking information will provide confidence to investors regarding the benefits of capital invested in the company. Also, the application of GCG will ensure that the company's operations and activities are following internal company rules and regulations as well as government regulations. Thus the existence of GCG will reduce the potential for fraud and contribute to stock liquidity. The conceptual framework of hypothesis development as follows:

Therefore, the hypothesis in this study include:

H1: Forward-looking information disclosure influences asymmetric information;

H2: Institutional ownership affects the asymmetric information;

H3: Foreign ownership affects the asymmetric information;

H4: Board activity affects asymmetric information;

H5: Forward-looking information disclosure affects stock liquidity through asymmetric information;

H6: Institutional ownership affects stock liquidity through asymmetric information;

H7: Foreign ownership affects stock liquidity through asymmetric information;

H8: Board activity affects stock liquidity through asymmetric Information.

\section{Research Methods}

In this study, the type of research used is causal research, which explains the effect of an independent variable on the dependent variable. The independent variables in this study are forward-looking information disclosure and GCG, while the dependent variable is stock liquidity. The total population of manufacturing companies listed on IDX is 145 companies. Furthermore, to calculate the number of samples from a particular population, the Slovin formula is used as follows:

$$
n=\frac{N}{1+N e^{2}}
$$

Explanation:

n1: Samples

N: Population

e: Error level or critical value

This sampling is carried out at a confidence level of $90 \%$ or a critical value of $10 \%$ so that the sample size can be calculated as follows:

$$
\begin{aligned}
& n=\frac{145}{1+145(0,1)^{2}} \\
& n=59.1
\end{aligned}
$$

\begin{tabular}{|c|c|c|}
\hline Variables & Measurement & Scale \\
\hline Stock Liquidity & $\begin{array}{l}\text { Trading volume activity (TVA) } \\
\text { TVA = Vi,t/ Si,t } \\
\text { Description: } \\
\text { Vi, } \mathrm{t}=\text { The trading volume for stock } \mathrm{i} \text { on year } \mathrm{t} \\
\mathrm{Si}, \mathrm{t}=\text { The outstanding for stock } \mathrm{i} \text { on year } \mathrm{t}\end{array}$ & Ratio \\
\hline Asymmetry Information & $\begin{array}{l}\text { Measured by the bid-ask spread. } \\
\text { SPREADit }=\frac{\text { Askit }- \text { Bidit }}{(\text { Askit }+ \text { bidit }): 2} \times 100\end{array}$ & Ratio \\
\hline $\begin{array}{l}\text { Forward-Looking } \\
\text { Information Disclosure }\end{array}$ & $\begin{array}{l}\text { Classify FLI into six categories that correspond to the six Content } \\
\text { Elements included in the Integrated Report Framework (Cheng et al., } \\
\text { 2014; Stubbs \& Higgins, 2014). } \\
\text { The contents of the elements are as follows: } \\
\text { 1) Organizational overview and external environment (ORG) } \\
\text { 2) Governance (GOV) } \\
\text { 3) Business model (BUS) } \\
\text { 4) Risks and opportunities (RISK) } \\
\text { 5) Strategy and resource allocation (STR) } \\
\text { 6) Performance (PERF) }\end{array}$ & Ratio \\
\hline Institutional Ownership & (Share ownership by institutional parties/outstanding share) x 100\% & Ratio \\
\hline Foreign Ownership & (Shares ownership by foreign/outstanding share) $\times 100 \%$ & Ratio \\
\hline Board Activities & the number of meetings of the board held for one year & Ratio \\
\hline
\end{tabular}

Table 1: Operationalization Variables 
Based on the calculations, the samples taken were 59 (rounded up) issuers per year with two years of annual reports and stock transactions from 2016-2017. The total data sampled was 118 data (59 issuers x 2 years). The data was taken from the IDX website. Furthermore, the operational variables are as follow:

The forward-looking information refers to the perspective of disclosure in integrated reporting. According to IIRC, 2013, there are six categories (perspectives), which are then broken down into 27 disclosure items, as presented in Table 2. The forward-looking score measurement was based on the disclosure index. Namely, the number of items revealed is divided by the total items.

The analytical method used in this study is multiple linear regression with the equation of the regression formula as follows:

$$
\begin{aligned}
\text { Bid_Ask }= & \alpha+\beta 1 \mathrm{DISCLOSURE}+\beta 2 \mathrm{KEP} \text { INST } \\
& +\beta 3 \mathrm{KEP} \_ \text {ASING }+\beta 4 \mathrm{ACT} \_\mathrm{DEWAN}+\mathrm{e} \\
\mathrm{TVA}= & \alpha+\beta 1 \mathrm{DISCt}+\beta 2 \mathrm{KEP} \text { INST } \\
& +\beta 3 \mathrm{KEP} \text { ASING }+\beta 4 \text { ACT_DEWAN } \\
& +\beta 5 \mathrm{Bid} \text { _Ask }+\mathrm{e}
\end{aligned}
$$

Explanation:

TVA: Stock Liquidity

Bid_Ask: Asymmetric Information

DISCLOSURE: Forward-Looking

Information Disclosure

\begin{tabular}{|c|c|}
\hline Categories & Topics of Informations \\
\hline $\begin{array}{l}\text { I. Organizational } \\
\text { Overview and External } \\
\text { Environment (ORG) }\end{array}$ & $\begin{array}{l}\text { 1. The organization's culture, ethics, and values } \\
\text { 2. The organization's ownership and operating structure } \\
\text { 3. The organization's principal activities and markets } \\
\text { 4. The organization's competitive landscape and market positioning } \\
\text { 5. The organization's position within the value chain } \\
\text { 6. Significant factors affecting the external environment and the organization's response }\end{array}$ \\
\hline II. Governance (GOV) & $\begin{array}{l}\text { 7. The organization's leadership structure including the skills and diversity } \\
\text { 8. Specific processes used to make strategic decisions and to establish and monitor the culture } \\
\text { of the organization } \\
\text { 9. Particular actions charged with governance to influence and monitor the strategic direction } \\
\text { of the organization and its approach to risk management } \\
\text { 10. The relationship between culture, ethics, and value with key stakeholders and capital } \\
\text { 11. Remuneration and incentives }\end{array}$ \\
\hline $\begin{array}{l}\text { III. Business Model } \\
\text { (BUS) }\end{array}$ & $\begin{array}{l}\text { 12. Key inputs } \\
\text { 13. Key business activities } \\
\text { 14. Key outputs } \\
\text { 15. Key outcomes }\end{array}$ \\
\hline $\begin{array}{l}\text { IV. Risks and } \\
\text { Opportunities (RISK) }\end{array}$ & $\begin{array}{l}\text { 16. A specific external source of risks and opportunities } \\
\text { 17. Specific internal source of risks and opportunities } \\
\text { 18. The organization's assessment of the likelihood that risk or opportunity will come to fruition } \\
\text { and the magnitude of its effect if it does } \\
\text { 19. The specific steps being taken to mitigate or manage key risks or to create value from key } \\
\text { opportunities }\end{array}$ \\
\hline $\begin{array}{l}\text { V. Strategy and } \\
\text { Resource Allocation } \\
\text { (STR) }\end{array}$ & $\begin{array}{l}\text { 20. The organization's short-, medium-, and long-term strategic objectives } \\
\text { 21. The strategies to achieve strategic objectives } \\
\text { 22. The resource allocation plans to implement the strategy } \\
\text { 23. The linkage between the organization's strategy and resource allocation plans } \\
\text { 24. What differentiates the organization to give it a competitive advantage and enable it to } \\
\text { create value }\end{array}$ \\
\hline VI. Performance (PERF) & $\begin{array}{l}\text { 25. The organization's effects on the capital } \\
\text { 26. The state of key stakeholder relationship and how the organization responds to key } \\
\text { stakeholder's legitimate needs and interests } \\
\text { 27. The linkage between current performance and the organization's outlook }\end{array}$ \\
\hline
\end{tabular}

INST/KEP INST: Institutional Ownership FOREIGN/KEP_ASING: Foreign Ownership BOARD_ACT/ACT_DEWAN: Board Activity

Table 2: Disclosure Topic in Integrated Reporting Perspectives Based on IIRC 2013 


\section{Results and Discussion}

Based on the results of data processing using Eviews 10 software the following results are obtained:

Remark:

- Organizational Overview And External Environment (ORG)

- Governance (GOV)

- Business Model (BUS)

- Risks and Opportunities (RISK)

- Strategy and Resource Allocation (STR)

- Performance (PERF)

The following is an explanation of the research variables based on descriptive statistical (table 3 ) results:

- ORG disclosure has six items, the maximum number of disclosure items is six, and the minimum is 0 . The average disclosure items are 3.49, and this reflects that disclosure of organizational aspects is around $58.16 \%$ of the total.

- Governance disclosure has five items, the maximum number of disclosure items is five and the minimum is 0 . The average disclosure items are 2.82, and this reflects that the disclosure of governance aspects is around $56.4 \%$ of the total.

- Business Model (BUS) disclosure has four items, the maximum number of disclosure items is four and the minimum is 2 . The average disclosure items are 2.21, and this reflects that the disclosure of business model aspects is around $55.2 \%$ of the total.

- Risk Disclosure (Risk) has four items, the maximum number of disclosure items is four and the minimum is 0 . The average disclosure items are 1.8, and this reflects that the disclosure of risk aspects is around $45.7 \%$ of the total.
- Disclosure Strategy (STR) has five items, the maximum number of disclosure items is five and the minimum is 0 . The average disclosure items are 2.64, and this reflects that the disclosure of strategy aspects is around $52.8 \%$ of the total.

- Performance Disclosure (PERF) has three items, the maximum number of disclosure items are three and the minimum 0 . The average disclosure items are 0.53 , and this reflects that the disclosure of performance aspects is around $17.7 \%$ of the total.

Disclosure of forward-looking information as a whole is still relatively low. The lowest disclosure is of performance aspects which only reached $17.7 \%$, whereas the disclosure of performance is the most important because of its strong relevance to the company's prospects.

Based on Graph 1 above, it can be seen that the JarqueBera value is 5.134646 and the significance probability is $0.076>\alpha 0.05$, which means that the residual data is normally distributed.
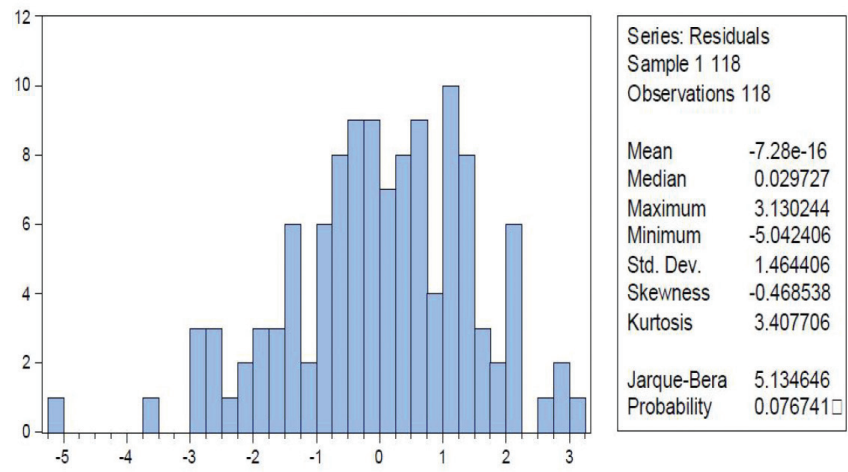

Figure 2: Histogram - Normality

Table 3: Descriptive Statistics

\begin{tabular}{|l|c|c|c|c|c|c|}
\hline & ORG & GOV & BUS & RISK & STR & PERF \\
\hline Mean & 3.491525 & 2.822034 & 2.211864 & 1.838983 & 2.644068 & 0.533898 \\
\hline Median & 3.000000 & 3.000000 & 2.000000 & 2.000000 & 2.000000 & 0.000000 \\
\hline Maximum & 6.000000 & 5.000000 & 4.000000 & 4.000000 & 5.000000 & 3.000000 \\
\hline Minimum & 0.000000 & 0.000000 & 2.000000 & 0.000000 & 0.000000 & 0.000000 \\
\hline Std. Dev. & 1.448523 & 1.075217 & 0.520547 & 1.240143 & 1.158583 & 0.675356 \\
\hline Skewness & -0.067804 & -0.097490 & 2.417533 & 0.145871 & 0.160165 & 1.214049 \\
\hline Kurtosis & 2.667665 & 2.754755 & 7.813796 & 2.127608 & 3.023766 & 4.520648 \\
\hline Jarque-Bera & 0.633443 & 0.482630 & 228.8733 & 4.160391 & 0.507281 & 40.35615 \\
\hline Probability & 0.728533 & 0.785594 & 0.000000 & 0.124906 & 0.775971 & 0.000000 \\
\hline Sum & 412.0000 & 333.0000 & 261.0000 & 217.0000 & 312.0000 & 63.00000 \\
\hline Sum Sq. Dev. & 245.4915 & 135.2627 & 31.70339 & 179.9407 & 157.0508 & 53.36441 \\
\hline Observations & 118 & 118 & 118 & 118 & 118 & 118 \\
\hline
\end{tabular}


The results of statistical processing according to Table 4 show that the coefficient value of each variable does not exceed 0.8 . Thus, it can be concluded that there is no multicollinearity between independent variables in the regression model.

Also, based on the results of the heteroscedasticity test shown in Table 5, the p-value Obs * R-Square 0.0415 $<0.05$; therefore, it can be concluded that there is no heteroscedasticity and the data is homogeneous.

From the results of the above output (table 6), the D-W value obtained from the regression model is 1.7609 . This value will be compared with the table value using a significance value of $5 \%$, the number of samples $118(\mathrm{n})$, and the number of independent variables $4(\mathrm{k}=4)$. So in the Durbin Watson table, the lower bound value ( $\mathrm{dl}$ ) is 1,612 with the upper limit (du) 1.7887. Durbin Watson's statistical results obtained 1.7609 are in the area $\mathrm{du}<\mathrm{dw}<4$-du $(1.7887<1.7609<2.2113$ or in the area where there is no autocorrelation.

Table 7 above shows the adjusted R Square value of 0.2296 or $22.96 \%$ before the asymmetry variable is entered as an intervening variable. The results show that $22.96 \%$ of the variation in the number of liquidity of shares (TVA) can be explained significantly by variations in future disclosure of information, institutional ownership, foreign ownership, and board activity. While $(100 \%-22.96 \%)=77.04 \%$ of the total liquidity of shares (TVA) can be explained by other variables.

Table 4: Multicollinearity Test

\begin{tabular}{|l|c|c|c|c|c|c|}
\hline & \multicolumn{1}{|l}{ Correlation } \\
\hline & LOG_LIQ & KEP_INST & KEP_ASING & ACT_DEWAN & DISCLOSURE & BID_ASK \\
\hline LOG_LIQ & 1.000000 & -0.232110 & -0.269138 & 0.014677 & 0.159776 & -0.232973 \\
\hline KEP_INST & -0.232110 & 1.000000 & 0.650003 & 0.030986 & 0.269821 & 0.021809 \\
\hline KEP_ASING & -0.269138 & 0.650003 & 1.000000 & -0.015468 & 0.133766 & -0.033112 \\
\hline ACT_DEWAN & 0.014677 & 0.030986 & -0.015468 & 1.000000 & 0.043958 & -0.048708 \\
\hline DISCLOSURE & 0.159776 & 0.269821 & 0.133766 & 0.043958 & 1.000000 & -0.187731 \\
\hline BID_ASK & -0.232973 & 0.021809 & -0.033112 & -0.048708 & -0.187731 & 1.000000 \\
\hline
\end{tabular}

Table 5: Heteroscedasticity Test

\begin{tabular}{|c|c|c|c|c|}
\hline Heteroskedasticity Test: White & & & & \\
\hline F-statistic & 2.428960 & \multicolumn{2}{|c|}{ Prob. $F(5,112)$} & 0.0394 \\
\hline Obs*R-squared & 11.54367 & \multicolumn{2}{|c|}{ Prob.Chi-Square(5) } & 0.0416 \\
\hline Scaled explained SS & 12.51957 & \multicolumn{2}{|c|}{ Prob. Chi-Square(5) } & 0.0283 \\
\hline \multicolumn{5}{|l|}{ Test Equation: } \\
\hline \multicolumn{5}{|l|}{ Dependent Variable: RESID^2 } \\
\hline \multicolumn{5}{|l|}{ Method: Least Squares } \\
\hline \multicolumn{5}{|l|}{ Date: $07 / 01 / 20$ Time $: 21: 14$} \\
\hline \multicolumn{5}{|l|}{ Sample: 1118} \\
\hline \multicolumn{5}{|l|}{ Included observations: 118} \\
\hline Variable & Coefficient & Std. Error & t-Statistic & Prob. \\
\hline $\mathrm{C}$ & 2.433663 & 2.000676 & 1.216420 & 0.2264 \\
\hline KEP_INST^2 & 0.000359 & 0.000138 & 0.000535 & 0.0106 \\
\hline KEP_ASING^2 & -0.000189 & 0.000163 & -1.157311 & 0.2496 \\
\hline ACT_DEWAN^2 & 1.21E-05 & 0.000215 & 0.056294 & 0.9552 \\
\hline DISCLOSURE^2 $^{\prime}$ & -4.012579 & 1.973202 & -2.033537 & 0.0444 \\
\hline BID_ASK^2 & 0.456039 & 0.375964 & 1.212983 & 0.227 \\
\hline R-squared & 0.097828 & \multicolumn{2}{|c|}{ Mean dependent var } & 2.126312 \\
\hline Adjusted R - squared & 0.057552 & \multicolumn{2}{|c|}{ S.D. dependent var } & 3.313423 \\
\hline S.E. of regression & 3.216663 & \multicolumn{2}{|c|}{ Akaike info criterion } & 5.224075 \\
\hline Sum squared resid & 1158.855 & \multicolumn{2}{|c|}{ Schwarz criterion } & 5.364957 \\
\hline Log likelihood & -302.2204 & \multicolumn{2}{|c|}{ Hannan-Quinn criter } & 5.281277 \\
\hline F-statistic & 2.428960 & \multicolumn{2}{|c|}{ Durbin-Watson stat } & 2.066501 \\
\hline Prob(F-statistic) & 0.039404 & & & \\
\hline
\end{tabular}


Table 6: Autocorrelation Test (Durbin Watson)

\begin{tabular}{|l|c|c|c|}
\hline R-squared & 0.166252 & Mean dependent var & -2.385125 \\
\hline Adjusted R-squared & 0.129031 & S.D. dependent var & 1.603778 \\
\hline S.E. of regression & 1.496737 & Akaike info criterion & 3.693961 \\
\hline Sum squared resid & 250.9049 & Schwarz criterion & 3.834843 \\
\hline Log likelihood & -211.9437 & Hannan-Quinn criter. & 3.751163 \\
\hline F-statistic & 4.466640 & Durbin-Watson stat & 1.760943 \\
\hline Prob(F-statistic) & 0.000951 & & \\
\hline
\end{tabular}

Table 7: Determination Coefficient Test (Information Asymmetry)

\begin{tabular}{|l|c|c|c|c|}
\hline Variable & Coefficient & Std. Error & t-Statistic & Prob. \\
\hline C & -1.553335 & 1.673573 & -0.928155 & 0.3553 \\
\hline KEP_INST & 0.003409 & 0.005631 & 0.605368 & 0.5461 \\
\hline KEP_ASING & 0.006621 & 0.006000 & 1.103374 & 0.2722 \\
\hline ACT_DEWAN & 0.001675 & 0.017162 & 0.097606 & 0.9224 \\
\hline DISCLOSURE & -5.983192 & 0.986851 & -6.062911 & 0.0000 \\
\hline R-squared & 0.255945 & Mean dependent var & -4.116125 \\
\hline Adjusted R - squared & 0.229607 & S.D. dependent var & 1.711212 \\
\hline S.E. of regression & 1.501966 & Akaike info criterion & 3.692875 \\
\hline Sum squared resid & 254.9168 & Schwarz criterion & 3.810277 \\
\hline Log likelihood & -212.8796 & Hannan-Quinn criter. & 3.740544 \\
\hline F-statistic & 9.717645 & Durbin-Watson stat & 1.821381 \\
\hline Prob(F-statistic) & 0.000001 & \multicolumn{3}{|l|}{} \\
\hline
\end{tabular}

Based on Table 7, it can be concluded that the variables of future information disclosure, institutional ownership, foreign ownership, and board activity simultaneously influence the information asymmetry such that the model is feasible to be used for research indicated by prob (F-statistic) $0.000001<0.05$. Also, referring to the results of the t-test in Table 6, the effect of each independent variable on the dependent variable can be explained as follows:

- The future information disclosure variable has a $t$-value of -6.062911 and Prob value. $0,000<0.05$. This shows that the future information disclosure variable has a negative and significant effect. Thus hypothesis $\mathrm{H} 1$ is accepted, which means the disclosure of future information has a negative and significant effect on information asymmetry.

- The institutional ownership variable has a t-value of 0.605368 and a Prob value. 0.5461>0.05. This shows that the institutional ownership variable (INST) has a positive but not significant effect. Thus hypothesis $\mathrm{H} 2$ is rejected, which means institutional ownership has no significant effect on information asymmetry
- The foreign ownership variable has a t-value of 1.103374 and a Prob value. $0.2722>0.05$. This shows that the foreign ownership variable (Kep_Asing) has a positive but not significant effect. Thus hypothesis $\mathrm{H} 3$ is rejected, which means foreign ownership has no significant effect on information asymmetry.

- The board activity variable has a t-value of 0.097606 and a Prob value. $0.9224>0.05$. This shows that the board activity variable (Act_Dewan) has a positive but not significant effect. Thus hypothesis $\mathrm{H} 4$ is rejected, which means that board activity has no significant effect on information asymmetry.

Table 8 shows the coefficient of determination that shows the adjusted R-square value of 0.1290 . This means that $12.90 \%$ of the variation in the number of liquidity of shares (TVA) can be explained significantly by variations in future disclosure of information, institutional ownership, foreign ownership, and board activities as well as information asymmetry as an intervening variable. Whereas (100\%$12.90 \%)=87.10 \%$ the amount of stock liquidity (TVA) can be explained by other variables. It can be concluded that with the information asymmetry, the adjusted $\mathrm{R}$ squared value decreases. 
Table 8: Test the Stock Liquidity Determination Coefficient through Information Asymmetry

\begin{tabular}{|l|c|c|c|c|}
\hline Variable & Coefficient & Std. Error & t-Statistic & Prob. \\
\hline C & -2.776683 & 1.680555 & -1.652242 & 0.1013 \\
\hline KEP_INST & -0.006871 & 0.005646 & -1.217046 & 0.2261 \\
\hline KEP_ASING & -0.010917 & 0.005997 & -1.820248 & 0.0714 \\
\hline ACT_DEWAN & -0.000434 & 0.017121 & -0.025338 & 0.9798 \\
\hline DISCLOSURE & 2.064914 & 1.004538 & 2.055586 & 0.0421 \\
\hline BID_ASK & -0.806512 & 0.354126 & -2.277471 & 0.0247 \\
\hline R-squared & 0.166252 & Mean dependent var & -2.385125 \\
\hline Adjusted R - squared & 0.129031 & S.D. dependent var & 1.603778 \\
\hline S.E. of regression & 1.496737 & Akaike info criterion & 3.693961 \\
\hline Sum squared resid & 250.9049 & Schwarz criterion & 3.834843 \\
\hline Log likelihood & -211.9437 & \multicolumn{2}{|c|}{ Hannan-Quinn criter. } & 3.751163 \\
\hline F-statistic & 4.466640 & \multicolumn{2}{|}{ Durbin-Watson stat } & 1.760943 \\
\hline Prob(F-statistic) & 0.000951 & \multicolumn{2}{|}{} \\
\hline
\end{tabular}

Based on Table 8, it can be concluded that the variables of future information disclosure, institutional ownership, foreign ownership, and board activity influence jointly on the information asymmetry which means that the model is suitable for use in research that is seen with a prob (F-statistic) value of $0,000951<0,05$. Furthermore, based on the results of the t-test in Table 8, the effect of each independent variable on the dependent variable can be explained as follows:

- The future information disclosure variable has a t-value of 2.055586 and a Prob value. 0.0421<0.05. This shows that the variable future information disclosure variable has a positive and significant effect. Thus hypothesis $\mathrm{H} 5$ is accepted, which means the future information disclosure variable has a significant effect on stock liquidity through information asymmetry.

- The institutional ownership variable has a t-value of -1.217046 and a Prob value. $0.2261>0.05$. This shows that the institutional ownership variable (INST) has a negative but not significant effect. Thus hypothesis H6 is rejected, which means institutional ownership has no significant effect on stock liquidity through information asymmetry.

- The foreign ownership variable has a t-value of -1.820248 and a Prob value. $0.0714>0.05$. This shows that the foreign ownership variable (Kep_Asing) has a negative but not significant effect. Thus hypothesis $\mathrm{H} 7$ is rejected, which means foreign ownership has no significant effect on stock liquidity through information asymmetry.
- The board activity variable has a t-value of -0.025338 and a Prob value. $0.9798>0.05$. This shows that the board activity variable (Act_Dewan) has a negative but not significant effect. Thus hypothesis H8 is rejected, which means that board activity has no significant effect on stock liquidity through information asymmetry

In theory, an increase in disclosure levels reduces the likelihood of asymmetric information, which is measured through bid-ask spreads, stock liquidity, and volatility of stock returns (Cormier et al., 2010). Disclosures can take a variety of circumstances, and not all types of information disclosure will have the same impact on the capital market. Both managers and policymakers are interested in ensuring which information is useful for investors and which can have an effect on the capital market. In particular, future information has become vital because historical information may not be enough for investors. Both organizations and researchers have stated the importance of future information to improve estimates about companies and facilitate the decision-making process in the capital market.

On the other hand, there is an ongoing debate about how investors value and interpret information disclosed by companies (Beyer et al., 2010). The higher the asymmetric information, the greater the bid-ask spread. In this case, financial statement disclosures are expected to reduce information asymmetry such that the bid-ask spread also decreases (Utami, 2006). The results of this study are in line with Bravo (2015), who stated that future information disclosure influences asymmetric information, which is proxied by stock volatility. 
With the principle of transparency in the implementation of CG, companies with high institutional ownership structures should have higher pressure to provide better disclosure. The average institutional ownership in the manufacturing sector is around $36.94 \%$ which is a small percentage and cannot reduce information asymmetry. This is in line with the research conducted by Purwanti (2013), who stated that institutional ownership does not affect asymmetric information.

Tan and Mahoney (2006) stated that the agency cost of multinational companies is higher than national companies. This is because other countries where the head office opens a subsidiary has different characteristics than the head office, making it difficult to supervise the foreign subsidiary that faces asymmetric information problems due to obstacles such as geographical and language problems.

The role of supervisory activities from the board of directors and disclosure is needed by investors to reduce the use of private control owned by large shareholders (Allegrini $\&$ Greco 2013). The effectiveness of the audit committee's performance can be measured through several characteristics possessed by the audit committee including expertise, activities of the audit committee, and the independence of the audit committee (Fiarti \& Chariri, 2016). The results of this study contradict Chariri and Januarti (2017), who stated that routine meetings allow audit committees to be more effective in monitoring financial reporting processes and internal control and to improve the quality of information produced by management such that asymmetric information can be reduced.

Aljifri and Hussainey (2007), claimed that the benefits of forward-looking information disclosure are to help investors in making investment decisions. The absence of forwardlooking information can cause an inaccurate forecast of company prospects. Forward-looking financial information will be available to users of financial statements regarding the company's predictions in the future, without having to predict the condition of the company such that users of financial statements can make maximum use of financial information (Nugraha et al., 2018; Nugraha et al., 2020; Palea, 2014). This study, in line with the research of Ammann et al. (2011), who argued that corporate disclosures reduce the risk of asymmetric information and increase liquidity and reduce capital costs.

In this study, institutional ownership as one of the elements of GCG is not in accordance with the statement that the higher the institutional ownership, the more liquid shares are traded. This is contrary to the research conducted by Sidhu (2016), who stated that the mechanism of GCG affects stock market liquidity. Companies with GCG practices increase stock market liquidity because it increases financial transparency, which results in reduced information asymmetry.
The concentration of ownership is the amount of the percentage of share ownership held by the public or private in the structure of share ownership of a company. If ownership concentration is dominated by external parties, it can reduce agency conflict between managers and shareholders, because majority shareholders can control management policies freely without causing conflict between block shareholders. This is contrary to the research conducted by Sidhu (2016), who stated that the mechanism of GCG affects stock market liquidity. Companies with GCG practices increase stock market liquidity because it increases financial transparency, which results in reduced information asymmetry.

Rhee and Wang (2009) state that foreign ownership has a significant negative effect on stock liquidity, while institutional ownership has a negative but not significant effect on stock liquidity. According to Rhee and Wang (2009), several potential mechanisms cause foreign ownership to have a negative influence on stock liquidity such as (1) greater asymmetric information caused by foreign ownership (2) greater volatility caused by foreign institution trading activities (3) reduced liquidity due to the presence of dominant traders and (4) inactive trading because of the buyhold strategy carried out by foreign institutions.

Agency theory requires complete and clear disclosures in financial statements. In this case, to be able to provide transparency in financial statements, it is necessary to be supported by the existence of an annual work program agenda of the audit committee and regular meetings held by the audit committee. Therefore, higher intensity of the meeting held by the audit committee is expected to increase compliance with mandatory disclosures such that it has an impact on the liquidity of shares traded on the stock exchange. This is contrary to the research conducted by Sidhu (2016), who stated that the mechanism of GCG affects stock market liquidity. Companies with GCG practices increase stock market liquidity because it increases financial transparency, which results in reduced asymmetric information.

\section{Conclusions}

Disclosure of forward-looking information has a significant negative effect on asymmetric information, while institutional ownership, foreign ownership, and board activity variables do not affect asymmetric information. Meanwhile, foreign ownership variables negatively affect stock liquidity through asymmetric information. This is related to inactive trading due to the purchasing strategy carried out by international institutions. Furthermore, asymmetric information has a significant negative effect on stock market liquidity. This is because higher asymmetric information will affect lower stock liquidity. Asymmetric information mediates the relationship between forward-looking disclosure with stock liquidity, and between foreign ownership and stock liquidity. 
Furthermore, the completeness and accuracy of information about the certainty of business activity both now and in the future can instill confidence in stakeholders in interacting and cooperating. Therefore to maintain that trust, it is necessary to implement comprehensive GCG in every business activity of a company.

\section{References}

Al-Najjar, B. (2012). The determinants of board meetings: Evidence from the categorical analysis. Journal of Applied Accounting Research, 13(2), 178-190. https://doi. org/10.1108/09675421211254867

Aljifri, K., \& Hussainey, K. (2007). The determinants of forwardlooking information in annual reports of UAE companies. Managerial Auditing Journal, 22(9), 881-894. https://doi. org/10.1108/02686900710829390

Alkhatib, K. (2014). The determinants of forward-looking information disclosure. In Procedia - Social and Behavioral Sciences, 109, 858-864. https://doi.org/10.1016/j.sbspro.2013. 12.554

Allegrini, M., \& Greco, G. (2013). Corporate boards, audit committees, and voluntary disclosure: Evidence from Italian listed companies. Journal of Management and Governance, 17(1), 187-216. https://doi.org/10.1007/s10997-011-9168-3

Altman, E. I. (1968). Financial ratios, discriminant analysis, and the prediction of corporate bankruptcy. The Journal of Finance, XXIII(4), 589-610.

Ammann, M., Oesch, D., \& Schmid, M. M. (2011). Corporate governance and firm value: International evidence. Journal of Empirical Finance, 18(1), 36-55. https://doi.org/10.1016/j. jempfin.2010.10.003

Anand, A., Irvine, P., Puckett, A., \& Venkataraman, K. (2013). Institutional trading and stock resiliency: Evidence from the 2007-2009 financial crisis. Journal of Financial Economics, 108(3), 773-797. https://doi.org/10.1016/j.jfineco.2013.01.007

Arnott, R., \& Stiglitz, J. E. (1988). Randomization with asymmetric information. The RAND Journal of Economics, 19(3), 344. https://doi.org/10.2307/2555661

Ball, R., \& Brown, P. (1968). An empirical evaluation of accounting income numbers. Journal of Accounting Research, 6(2), 159178. https://doi.org/10.4324/9780203067024

Ball, R., Jayaraman, S., \& Shivakumar, L. (2012). Audited financial reporting and voluntary disclosure as complements: A test of the confirmation hypothesis. Journal of Accounting and Economics, 53(1-2), 136-166. https://doi.org/10.1016/j. jacceco.2011.11.005

Beretta, S., \& Bozzolan, S. (2004). A framework for the analysis of firm risk communication. International Journal of Accounting, 39(3), 265-288. https://doi.org/10.1016/j.intacc.2004.06.006

Beyer, A., Cohen, D. A., \& Walther, B. R. (2010). The financial reporting environment : a review of the recent literature. Journal of Accounting and Economics, 50(2-3), 296-343. https://
EconPapers.repec.org/RePEc:eee:jaecon:v:50:y:2010:i:23:p:296-343

Blackwell, D. W., Noland, T. R., \& Winters, D. B. (1998). The value of auditor assurance: Evidence from loan pricing. Journal of Accounting Research, 36(1), 57. https://doi. org/10.2307/2491320

Bravo, F. (2015). Forward-looking disclosure and corporate reputation as mechanisms to reduce stock return volatility. Revista de Contabilidad, 19(1), 122-131. https://doi.org/10. 1016/j.rcsar.2015.03.001

Chariri \& Januarti. (2017). Eksplorasi Elemen Integrated Reporting Dalam, XXI(September), 411-424. https://doi.org/10.24912/ ja.v21i3.245

Cheng, M., Green, W., Conradie, P., Konishi, N., \& Romi, A. (2014). The international integrated reporting framework: Key issues and future research opportunities. Journal of International Financial Management and Accounting, 25(1), 90-119. https:// doi.org/10.1111/jifm.12015

Chhaochharia, V., \& Grinstein, Y. (2007). Corporate governance and firm value: The impact of the 2002 governance rules. Journal of Finance, 62(4), 1789-1825. https://doi.org/10.1111/ j.1540-6261.2007.01257.x

Chung, K. H., Elder, J., \& Kim, J. C. (2010). Corporate governance and liquidity. Journal of Financial and Quantitative Analysis, 45(2), 265-291. https://doi.org/10. 1017/S0022109010000104

Cormier, D., Ledoux, M. J., Magnan, M., \& Aerts, W. (2010). Corporate governance and information asymmetry between managers and investors. Corporate Governance, 10(5), 574589. https://doi.org/10.1108/14720701011085553

Cornett, M. M., Marcus, A. J., Saunders, A., \& Tehranian, H. (2007). The impact of institutional ownership on corporate operating performance. Journal of Banking and Finance, 31(6), 1771-1794. https://doi.org/10.1016/j.jbankfin.2006. 08.006

Dalton, D. R., Hitt, M. A., Certo, S. T., \& Dalton, C. M. (2007). The fundamental agency problem and its mitigation. The Academy of Management Annals, 1(1), 1-64. https://doi. org/10.5465/078559806

Duarte, J., Han, X., Harford, J., \& Young, L. (2008). Information asymmetry, information dissemination, and the effect of regulation FD on the cost of capital. Journal of Financial Economics, 87(1), 24-44. https://doi.org/10.1016/j.jfineco. 2006.12.005

Edelman, R. B., \& Baker, H. K. (1990). Liquidity and stock exchange listing. Financial Review, 25(2), 231-249. https:// doi.org/10.1111/j.1540-6288.1990.tb00794.x

Fama, E. F. (1969). The adjustment of stock prices to new information. International Economic Review, 10, 1-21.

Fiarti, D., \& Chariri, A. (2016). The effect of the characteristics of the audit committee on the scope of integrated reporting. Universitas Diponegoro. Retrieved from http://eprints.undip. ac.id/48834/ 
Forddanta, D. H. (2016). IDX transaction liquidity is still imbalanced. Retrieved March 27, 2020, from https://investasi. kontan.co.id/news/likuiditas-transaksi-bei-masih-timpang

Gillan, S. L., \& Starks, L. T. (2005). Corporate governance, corporate ownership, and the role of institutional investors: A global perspective. Journal of Applied Finance, 13(2), 4-22. https://doi.org/10.2139/ssrn.439500

Goodwin, J. (2003). The relationship between the audit committee and the internal audit function: Evidence from Australia and New Zealand. International Journal of Auditing, 7(3), 263278. https://doi.org/10.1046/j.1099-1123.2003.00074.x

Herring, R. J., \& Carmassi, J. (2008). The structure of cross-sector financial supervision. Financial Markets, Institutions, and Instruments, 17(1), 51-76. https://doi.org/10.1111/j.14680416.2007.00132.x

Hidayah, N., Badawi, A., \& Nugroho, L. (2019). Factors affecting the disclosure of sustainability reporting. International of Commerce of Commerce and Finance, 5(2), 219-229.

Igawa, K., \& Kanatas, G. (1990). Asymmetric information, collateral, and moral hazard. The Journal of Financial and Quantitative Analysis, 25(4), 469-490.

IPOTNews. (2017). Stock liquidity is still IDX's PR. Retrieved March27, 2020, from https:/www.indopremier.com/ipotnews/newsDetail. php?jdl=Likuiditas_Saham_masih_Jadi_PR_BEI\&news_ $\mathrm{id}=320158 \&$ group_news $=$ RESEAR $\overline{\mathrm{CHN}} \overline{\mathrm{EW}}$ - $\&$ news_date $=\&$ taging_subtype $=$ BUMIMERUGI\&name $=\&$ search $=y_{-}$ general\&q=saham, \&halaman $=1$

Jensen, M., \& Meckling, W. (1976). Theory of the firm: Managerial behavior, agency costs, and ownership. Strategic Management Journal, 21(4), 1215-1224. Retrieved from http://search. ebscohost.com/login.aspx?direct $=$ true $\& d b=$ buh $\& A N=122433$ $01 \&$ site $=$ ehost-live

La Porta, R., Lopez-de-Silanes, F., \& Shleifer, A. (1999). Corporate ownership around the world. Journal of Finance, 54(2), 471517. https://doi.org/10.1111/0022-1082.00115

Lai, S., Lin, C., Lee, H., \& Wu, F. (2009). An empirical study of the impact of Internet financial reporting on stock prices. The British Journal of Psychiatry, 111(479), 1009-1010. https:// doi.org/10.1192/bjp.111.479.1009-a

Lata, P. (2020). The Influences of Participatory Management and Corporate Governance on the Reduction of Financial Information Asymmetry: Evidence from Thailand. Journal of Asian Finance, Economics and Business, 7(11), 853-866. https://doi.org/10.13106/jafeb.2020.vol7.no11.853

Loukil, N., \& Yousfi, O. (2012). Does corporate governance affect stock liquidity in the tunisian stock market? In In 29th International Conference of the French Finance Association (AFFI) (pp. 1-33). https://doi.org/10.1227/01. NEU.0000349921.14519.2A

Napitupulu, S., Primiana, I., Nidar, S. R., Effendy, N., \& Puspitasari, D. M. (2020). The effect of management capabilities in implementing good corporate governance: A study from indonesia banking sector. Journal of Asian Finance, Economics and Business, 7(1), 159-165. https://doi.org/10.13106/ jafeb.2020.vol7.no1.159

Nofsinger, J. R. (2001). The impact of public information on investors. Journal of Banking and Finance, 25(7), 1339-1366. https://doi.org/10.1016/S0378-4266(00)00133-3

Nugraha, E., Nugroho, L., \& Dwijayanty, R. (2018). Audit rotation a phenomenological study. In: Seminar Nasional dan Diskusi Panel Multidisiplin Hasil Penelitian \& Pengabdian kepada Masyarakat (pp. 165-170).

Nugraha, E., Nugroho, L., \& Setiawan, A. (2020). Discourses of determinants factor in audit quality. In The 1st Annual Conference Economics, Business, and Social Sciences. https:// doi.org/10.4108/eai.26-3-2019.2290776

Nugroho, L., \& Nezzim Bararah, H. (2018). The influence of good corporate governance and operational costs and operating income (BOPO) on the financial stability of Islamic commercial banks in Indonesia 2012-2017. Jurnal Inovasi Dan Bisnis, 6(2), 160-169. Retrieved from www.ejournal.polbeng.ac.id/index. php/IBP

Palea, V. (2014). Fair value accounting and its usefulness to financial statement users. Journal of Financial Reporting and Accounting, 12(2), 102-116. https://doi.org/10.2139/ ssrn. 2365712

Pernamasari, R. (2018). Implementation of good corporate governance and voluntary disclosure compliance: 100 compass index companies listed Indonesian Stock Exchange (IDX) 2015-2016. International Journal of Academic Research in Accounting, Finance and Management Sciences, $8(2), \quad 235-249 . \quad$ https://doi.org/10.6007/IJARAFMS/v8i $2 / 4316$

Purwanti, T. (2013). The impact of corporate governance mechanism on the asymmetric information. Kiat Bisnis, 5(2), 129-147.

Rhee, S. G., \& Wang, J. (2009). Foreign institutional ownership and stock market liquidity: Evidence from Indonesia. Journal of Banking and Finance, 33(7), 1312-1324. https://doi. org/10.1016/j.jbankfin.2009.01.008

Sarens, G., De Beelde, I., \& Everaert, P. (2009). Internal audit: A comfort provider to the audit committee. British Accounting Review, 41(2), 90-106. https://doi.org/10.1016/j. bar.2009.02.002

Sidhu, M. K. (2016). Corporate governance and stock market liquidity. Journal of Commerce and Accounting Research, 5(3), 12-20. https://doi.org/10.21863/jcar/2016.5.3.033

Skouloudis, A., Evangelinos, K., \& Kourmousis, F. (2010). Assessing non-financial reports according to the global reporting initiative guidelines: Evidence from Greece. Journal of Cleaner Production, 18(5), 426-438. https://doi. org/10.1016/j.jclepro.2009.11.015

Stubbs, W., \& Higgins, C. (2014). Integrated reporting and internal mechanisms of change. Accounting, Auditing, and Accountability Journal, 27(7), 1068-1089. https://doi. org/10.1108/AAAJ-03-2013-1279 
Suryawijaya, M. A., \& Setiawan, F. A. (1998). The reaction of the Indonesian capital market to domestic political events (Event Study on the 27 July 1996 incident). KELOLA Gadjah Mada University Business Review.

Suryo, M., Nugraha, E., \& Nugroho, L. (2019). The importance of a going concern audit opinion and its determination. Inovbiz: Jurnal Inovasi Bisnis, 7(2), 123-130.

Tan, D., \& Mahoney, J. T. (2006). Why a multinational firm chooses expatriates: Integrating resource-based, agency, and transaction costs perspectives. Journal of Management Studies, 43(3), 457-484. https://doi.org/10.1111/j.1467-6486. 2006.00598.x

Utami, W. (2006). Impact of voluntary disclosure and earnings management on information asymmetry. Media Riset Akuntansi, Auditing \& Informasi, 6(1), 19-49.

Utami, Wiwik, Nugroho, L., \& Farida. (2017). Fundamental versus technical analysis of investment: a case study of investors' decisions in Indonesia stock exchange. The Journal of Internet Banking and Commerce, 22(8), 1-18.

Utami, W., Nugroho, L., Mappanyuki, R., \& Yelvionita, V. (2020). Early warning fraud determinants in banking industries. Asian Economic and Financial Review, 10(6), 604-627. https://doi. org/10.18488/journal.aefr.2020.106.604.627
Vafeas, N. (1999). Board meeting frequency and firm performance. Journal of Financial Economics, 53(1), 113-142. https://doi. org/10.1016/S0304-405X(99)00018-5

Vania, A. S., Nugraha, E., \& Nugroho, L. (2018). Does earning management happen in the Islamic bank? (Indonesia and Malaysia comparison). International Journal of Commerce and Finance. 4,1-6. from https://databoks.katadata.co.id

Wang, A. W., \& Zhang, G. (2009). Institutional ownership and credit spread: An information asymmetry perspective. Journal of Empirical Finance, 16(4), 597-612. https://doi.org/10.1016/j. jempfin.2009.04.002

Wang, M., \& Hussainey, K. (2013). Voluntary forward-looking statements are driven by corporate governance and their value relevance. Journal of Accounting and Public Policy, 32(3), 2649. https://doi.org/10.1016/j.jaccpubpol.2013.02.009

Wyatt, A. (2008). What financial and non-financial information on intangibles is value-relevant? A review of the evidence. Accounting and Business Research, 38(3), 217-256. https:// doi.org/10.1080/00014788.2008.9663336

Xu, X., \& Wang, Y. (1999). Ownership structure and corporate governance in Chinese stock companies. China Economic Review, 10(1), 75-98. https://doi.org/10.1016/S1043-951X(99)00006-1 